\title{
PRESENTACIÓN
}

\section{Jazz en América Latina}

Los cuatro artículos que han sido seleccionados para este número especial de Revista Musical Chilena aportan con diferentes miradas al fenómeno de la inserción del jazz en territorios culturalmente diferentes. Si entendemos el jazz como música afronorteamericana exportada a latitudes que fungen como periferia del mundo occidental, no podemos soslayar las relaciones de asimetría que conlleva este proceso. La hegemonía que Estados Unidos de Norteamérica ha desempeñado en Occidente desde principios del siglo XX en el ámbito económico, político, militar y cultural, transforma a la expansión del jazz en América Latina en un vector de connotaciones musicales y extramusicales. De estas situaciones dan cuenta los escritos que se presentan en este número de Revista Musical Chilena.

El primer trabajo, de la argentina Berenice Corti, parte exponiendo situaciones generales de la experiencia de integrar el jazz en países latinoamericanos, experiencias que son analizadas a la luz de los estudios que surgen en los países donde se han publicado las historias locales del género, y en escritos que abordan las problemáticas derivadas de esto.

Un aspecto central que Corti destaca en esta mirada regional es el contraste y el diálogo que ha acompañado la inserción del jazz en América Latina, así como también la incorporación de elementos musicales latinos en el jazz desarrollado dentro de las fronteras de Estados Unidos. En este proceso, de sentido bidireccional, se destaca el proceso de diálogo y diferenciación entre las categorías de latin jazz, propia de la experiencia del jazz norteamericano influenciado por la música latina, y el "jazz latino", inherente a los músicos latinos que se apropian de recursos jazzísticos para seguir desarrollando su música latina.

A partir de este enfoque regional, Corti también aborda la experiencia argentina en su relación particular con el jazz. En su estudio confluyen reflexiones que activan y cuestionan conceptos como identidad, nación y raza. Sus reflexiones culminan con un llamado a replantearnos lo que han sido y serán, de aquí en adelante, los relatos historiográficos respecto del jazz de/en nuestros países.

El segundo artículo es de la etnomusicóloga, pianista y compositora brasileña Marília Giller. La autora presenta una panorámica del cultivo del jazz en Brasil, asumido como un proceso que ha transitado por diferentes etapas, definidas por la función social que el jazz representa en cada una de ellas. Su relato da cuenta de la intensa actividad de orquestas brasileñas con formato de big band activas en el medio musical local, seguido de otro momento en que se producen géneros mixtos (como el samba-boogie, en 1945). Este proceso culmina en 1958 con el surgimiento de la bossa nova, entendida como un género musical brasileño con influencia (entre otros referentes) del jazz moderno.

El desarrollo del samba-jazz a principios de las década de 1960 confirmaría la posibilidad de gestionar en Brasil un híbrido musical que reconocía la impronta 
más evidente del jazz norteamericano, a pesar de la tradicional resistencia de la cultura musical brasileña a las influencias musicales provenientes de Estados Unidos.

La última etapa que describe Giller en su panorámica del jazz en Brasil se relaciona con el decantamiento de la música instrumental brasileña, género musical cultivado por músicos como Hermeto Pascoal y Egberto Gismonti, quienes además lograron una exposición internacional de sus propuestas musicales. Giller pone énfasis en la relación compleja, y a ratos conflictiva, entre la música popular brasileña y el jazz norteamericano, valiéndose de la teoría de "fricción de musicalidades", de Acacio Piedade, para graficar y explicar histórica y estilísticamente esta relación.

El tercer artículo también corresponde a un estudio de caso centrado en un país latinoamericano. El texto pertinente a jazz en República Dominicana, escrito por Darío Tejeda, aplica un enfoque transfronterizo. Este enfoque destaca la particular dinámica cultural que han tenido República Dominicana y Estados Unidos, facilitada por su cercanía geográfica y coyunturas históricas. Por una parte, Tejeda enfatiza el origen común afroamericano de las culturas musicales dominicanas y del sur de Estados Unidos, por ser parte de la Zona Caribe. En esta región, tanto Santo Domingo (como capital de República Dominicana) como Nueva Orleans (como cuna del jazz según la historiografía oficial) compartieron ancestros culturales comunes. Tejeda destaca la opinión de autores locales postulando la existencia de elementos musicales afrodominicanos compartidos con los orígenes del jazz, por hacer parte de esos ancestros.

$\mathrm{Al}$ igual que en el caso del jazz en Brasil, narrado por Giller, Tejeda reconoce la existencia de una relación conflictiva entre la música dominicana y el jazz. Parte de esta situación de conflicto derivó de la ocupación militar impuesta por Estados Unidos en el territorio dominicano entre 1916 y 1924. Dicha ocupación hizo parte de la política exterior norteamericana hacia América Latina, sumándose a la influencia que en el caso cultural (y específicamente en lo musical) representaba la exportación e influencia del jazz en las naciones al sur del río Bravo.

En un proceso similar a lo ocurrido en Brasil, Argentina y Chile, el jazz norteamericano se instaló en República Dominicana gracias a la industria musical, fomentando la actividad discográfica y el uso de formatos instrumentales específicos, como las big bands. Una vez consolidado como repertorio popular, urbano y masivo, el jazz en República Dominicana también contribuyó a gestionar géneros musicales locales de carácter híbrido, como el meren-jazz. Otro aspecto que Tejeda destaca en la relación entre República Dominicana y Estados Unidos fue la constante migración de músicos dominicanos que se radicaron en Nueva York. Este proceso se realizó desde la década de 1930 en adelante, permitiendo que varios músicos dominicanos no solo llevasen su música a Nueva York, sino además pudieran integrarse y aportar a la escena del latin jazz estadounidense.

El cuarto artículo de esta serie, "Mujeres en el jazz en Chile: Modelización, régimen simbólico y trayectorias de género", de Miguel Vera Cifras, es otro estudio de caso, pero más específico que los de Giller y Tejeda, pues se focaliza en el rol de la mujer en el contexto del jazz en Chile. Vera Cifras explora la situación de 
la mujer cantante de jazz en el devenir histórico de la práctica del jazz en Chile. Para ello el autor se basa en el concepto de modelización, asociándolo a procesos de aprendizaje social y gestión de roles en el medio jazzístico chileno, un medio notoriamente definido por criterios androcéntricos.

Según Vera Cifras, la función de la mujer cantante de jazz no solo se remite al modelo concreto de la intérprete jazzística de origen norteamericano, sino que está además definida por modelos anteriores, como lo fueron la vedette (según un modelo francés) y la cupletista (modelo español). En todos los casos, Vera Cifras distingue un juego simbólico que transita desde la frivolización a la sublimación de la cantante, llegando a ser asumida como un personaje, percibido como tal tanto por el público como por el mercado del espectáculo. Todo ello traspasado por los discursos de los entendidos y la prensa especializada.

En esta narrativa, el recorrido de las mujeres en el jazz chileno hace parte de la particular evolución del género jazzístico, en cuanto a su tránsito como música popular de carácter masivo y comercial, hasta ser considerado como música con valor artístico. En este sentido, Vera Cifras destaca (y saca del olvido) a algunas exponentes del canto jazzístico que debieron asumir en su gestión todas las transiciones antes mencionadas. El autor entonces pasa revista a las trayectorias de cantantes como Mirella Latorre, Kerry Keller o Teresa Orrego Salas, quienes debieron lidiar con la resistencia de sus familias de origen acomodado por vincularse a un ambiente aún marcado por el vedetismo y el rechazo de la vida nocturna como un espacio adecuado de desarrollo profesional para una mujer. Otras mujeres, como Malú Gatica o Carmen Barros, se destacaron en el canto profesional (y eventualmente jazzístico) a partir de su actividad principal como actrices. Como final de un proceso de decantación, el autor identifica la consolidación de un perfil de cantante femenina de jazz, o lady crooner, recién en la década de 1960, con figuras como Rita Góngora y Sophie Brown.

Creemos que estos cuatro artículos seleccionados para este número especial de Revista Musical Chilena serán un aporte a la gestación de una óptica latinoamericana respecto de los desarrollos del jazz en la región, considerando las similitudes y diferencias que es posible hallar en la gestación de estas historiografías locales. Finalmente, es posible destacar que los cuatro autores reseñados son integrantes de la rama latinoamericana de la Asociación Internacional para el Estudio de la Música Popular (IASPM-AL), y en particular del grupo de trabajo "Jazz en América Latina", un espacio de reflexión e intercambio intelectual que ha demostrado su eficacia al momento de poner en sintonía la pluralidad de voces que integran el mundo académico del continente.

Álvaro Menanteau Aravena Universidad de Santiago de Chile, Chile alvaro.menanteau@usach.cl 
